\title{
Krisen om Qatar og regional sikkerhed
}

\section{Af Lars Erslev Andersen}

Krisen i Golfstaternes organisation Gulf Cooperation Council (GCC) blev indledt den 5. juni 2017, da Saudi-Arabien sammen med Forenede Arabiske Emirater (UAE), Bahrain, Egypten og Yemens eksilregering afbrød de diplomatiske forbindelser til Qatar og underlagde den lille stat en blokade, udviste qatarer fra Saudi-Arabien og pålagde dem forbud mod indrejse til kongeriget.

I midten af august 2017 meddelte Saudi-Arabien, at borgere fra Qatar kunne få tilladelse til gennemføre pilgrimsrejse til Mekka og Medina under den årlige hajj, der i år indledtes den 30 . august.

Tilladelsen til, at qatarer måtte gennemføre pilgrimsrejse i Saudi-Arabien, kunne ses som en opblødning i konflikten, fordi den kom i stand efter det første møde mellem topfolk fra Qatar og Saudi-Arabien - men det er næppe tilfældet. Saudi-Arabien, der smykker sig med titlen 'Vogter af de to helligsteder Mekka og Medina, har internationalt forpligtet sig til at facilitere muslimer fra alle afkroge i verden til at kunne gennemføre hajj, og det ville være et klart selvmål at nægte qatarer denne religiøse pligt, fordi saudierne ville blive beskyldt for at politisere hajjen.

Der har tidligere været krise med Iran omkring gennemførelse af iranske muslimers rejse til Mekka og Medina, hvor Saudi-Arabien nægtede dem indrejse med den begrundelse, at iranere under en tidligere hajj havde benyttet lejligheden til at sprede politisk propaganda. Et kvotesystem har efterfølgende i årevis muliggjort, at selv pilgrimme fra Saudi-Arabiens ærkerival Iran kan rejse til helligstederne, og det ville have været et stort problem for det billede af en sand islamisk stat, som Saudi-Arabien sælger sig selv med, hvis de nægtede fromme muslimer fra Qatar at opfylde et af de fem krav, som Islam stiller til muslimerne.

Qatar stillede en række spørgsmål til Saudi-Arabien, herunder især om sine borgeres sikkerhed, dersom de valgte at rejse til Mekka. Det kom der ingen svar på, og derfor tog ingen qatarer på pilgrimsrejse, hvilket har efterladt dette års religiøse hajj dybt politiseret.

\section{Omgåelse af blokaden}

Økonomisk ser det allerede nu ud til, at

Lars Erslev Andersen, seniorforsker hos DIIS, med speciale i bl.a. international sikkerhedspolitik og Den Persiske Golf, Yemen og de palæstinensiske områder. 
bekymring for, om den ville have negativ indflydelse på planlægningen af VM i fodbold i 2022, men Qatar oplyste i slutningen af august, at forberedelserne - herunder opførelse af stadions, metro og togbaner - forløber uanfægtet af krisen, fordi Qatar hurtigt etablerede nye forsyningsruter.

Selvom informationerne stammer fra Qatar og medier som al-Jazeera, der har hovedkvarter i hovedstaden Doha og finansielt er støttet af Qatars emir og derfor skal tages med det forbehold, at Qatar naturligvis gerne vil fremstille det, som om landet er helt uanfægtet af blokaden, ser det faktisk ud, at til den kun har haft begrænset indflydelse på forsyningen af dagligvarer, økonomi og den generelle situation i Qatar.

Naturligvis er Qatar som alle andre olieog gaseksporterende lande også økonomisk blevet ramt af de faldende energipriser på verdensmarkedet, men landets reserver per capita er betydeligt større end fx Saudi-Arabiens. Mens Saudi-Arabien således kæmper med at skaffe nye indtægter i takt med, at deres reserverer skrumper ind, kan lille Qatar notere sig 340 milliarder dollar i reserver i Qatars Central Bank.

Det virkede ellers ganske dramatisk, da Saudi-Arabien, Bahrain, UAE, Egypten og den yemenitiske eksilregering $\mathrm{i}$ juni afbrød de diplomatiske forbindelser til Qatar, udviste qatarer fra deres lande - ja, selv omkring 15.000 qatarske kameler blev sendt hjem fra Saudi-Arabien - indstillede al samhandel og forbød brug af deres luftrum, territorialfarvande og landjord til transport af varer og personer til og fra Qatar.

Den internationale fodboldverden ytrede som nævnt bekymring for afviklingen af VM slutrunden i 2022 - nogle så måske ligefrem en mulighed for at få flyttet slutrunden væk fra Qatar, hvis ørkenklima og lille befolkning for mange har gjort placeringen af så stor en begivenhed dér surrealistisk og grotesk. Deres kritik blev forstærket af afviklingen af VM i landevejscykling i Qatar i 2016, hvor flere cykelryttere simpelthen kollapsede under varmen, mens feltet svedte derudaf uden den sædvanlige opbakning fra tilskuere, som simpelthen blev væk. Selvom Qatar opfører 8 - 9 luksusstadions, der er forsynet med aircondition, er slutrunden på grund af varmen flyttet til vinterhalvåret; hertil kommer, at de eksorbitant dyre stadions bygges af gæstearbejdere under forhold, som menneskerettighedsorganisationer har betegnet som slavelignende.

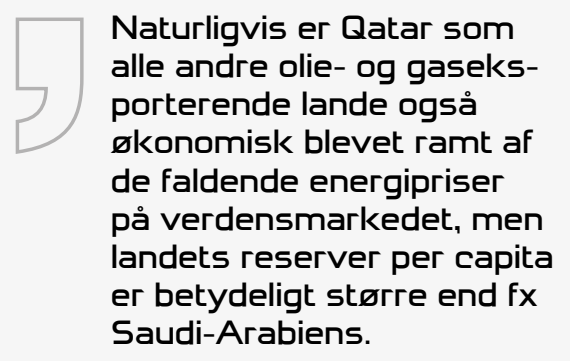

Derfor er der mange i fodboldverdenen, der gerne så, at slutrunden kunne flyttes til fx Europa. Saudi-Arabien og de øvrige arabiske stater i blokaden havde formentlig håbet på, at den ville fremtvinge så store forstyrrelser i planlægningen af slutrunden, at Qatar og Det Internationale Fodboldforbund ville blive tvunget til at flytte den et andet sted hen, hvilket ville være et prestigetab for Qatar af de helt store. Indtil videre ser det dog ikke ud til at gå sådan, og i slutningen af august tydede det faktisk på, at Qatar trods øgede $ø$ konomiske udgifter og store tab var bedre rustet til en langvarig krise end Saudi-Arabien. Med mindre Saudi-Arabien og de fire andre stater eskalerer krisen. 


\section{Krisens kerne}

Krisens kerne er imidlertid hverken fodbold eller økonomi, men politik. Det handler om, hvem der skal bestemme Den Arabiske Halvøs rolle i Mellemøsten og internationale forhold. Saudi-Arabien med stærk støtte fra UAE vil her svinge taktstokken og har i årevis været udfordret af og stærkt irriteret over, at Qatar er gået sine egne veje og med en vis succes har ført sin egen internationale politik både i forholdet til Iran, Det Muslimske Broderskab, FN og USA og ikke mindst i de regionale konflikter i Mellemøsten, i Libyen, Egypten, Syrien og Yemen samt i forholdet til Israel, som Qatar har handelsrelationer til. Dertil kommer Qatars støtte til Hamas og ikke mindst til det arabiske Mellemøstens vigtigste nyhedsmedie al-Jazeera.

\section{Krisens kerne er imidler- tid hverken fodbold eller økonomi, men politik. Det handler om, hvem der skal bestemme Den Arabiske Halvøs rolle i Mellemøsten og internationale forhold.}

Det er måske misvisende at tale om en decideret rivalisering mellem mægtige Saudi-Arabien og lille Qatar, men ikke desto mindre har Qatar nærmest systematisk og ofte med succes fulgt andre linjer end Saudi-Arabien. Den helt store irritation og vrede over Qatars egenrådige politik kom med Qatars støtte til Det Arabiske Forår og Det Muslimske Broderskab i Egypten.

Mens den vestlige verden jublede i begejstring over reformkræfterne, herunder anerkendte, hvad de kaldte de moderate islamiske oppositionsbevægelser, reagerede Saudi-Arabien og UAE med lodret konfrontation mod reformkræfterne og tillod ingen opposition at få ordet hverken i Saudi-Arabien eller UAE.
Da oppositionen i Bahrain fik bred opbakning til sine demonstrationer i februar og marts 2011, tøvede Saudi-Arabien og UAE ikke med at sende militær til den bahrainske kongefamilies undsætning. Lige siden har oppositionen i Bahrain været voldsomt undertrykt med militære midler og brutal nedkæmpelse af enhver form for kritik af kongefamilien. Beskeden fra Riyadh og Abu Dhabi har simpelthen været, at enhver indrømmelse til oppositionen i retning af en begyndende overgang til konstitutionelt demokrati, der kan åbne for demokratiske reformer, vil blive bremset med alle tilgængelige midler.

Her har Qatar spillet dobbeltspil, idet emirfamilien ikke har vist villighed til at afgive en tøddel af sin enevældige magt på hjemmefronten, men på udebanen omvendt har støttet islamiske oppositionsgrupper og reformkræfter i Mellemøsten, herunder i Egypten, De Palæstinensiske Områder og faktisk også i UAE. Derimod har Qatar holdt sig ude af Bahrain, fordi det ville være alt for sensitivt at støtte oppositionen dér, og faktisk var al-Jazeera bemærkelsesværdig fraværende under de store demonstrationer i foråret 2011, som vi kun var ganske få vestlige forskere og journalister, der fulgte på nærmeste hold på den nu fjernede 'Perleplads' (The Pearl Roundabout).

Qatars internationale politiske strategi har ganske enkelt været at gøre sig til en så vigtig og central spiller som mulig både diplomatisk som mægler og som økonomisk sponsor og dermed stille sig rådighed for det internationale samfund som en vigtig aktør, og den strategi er til UAE's og Saudi-Arabiens fortrydelse lykkedes al for godt.

Emirens strategi har således været at sikre Qatars modernisering ved systema- 
tisk at lægge afstand til Saudi-Arabien og UAE og føre en alternativ international politik. Et paradeeksempel på denne politik er placeringen af US Central Command (CENTCOM), hovedkvarteret for de amerikanske militære operationer i Mellemøsten, og flybasen al-Udeid, som USA brugte i krigen mod Irak og i dag i krigen mod Islamisk Stat. Placeringen blev besluttet i 2002 under optakten til Irakkrigen, efter at Saudi-Arabien havde meddelt USA, at den store og netop færdigbyggede Sultan base uden for Riyadh ikke måtte bruges i angrebene mod Irak. Herefter tilbød Qatar sig selv som vært for både flybase og CENTCOM og gjorde sig dermed til en vigtig strategisk partner for USA.

Blokaden mod Qatar har det primære sigte at fratage Qatar sin aktivistiske rolle i såvel regional som international politik eller sagt med andre ord: banke Qatar tilbage i den saudiarabiske fold.

\section{Qatar og Saudi-Arabien}

Frem til 1995 havde Saudi-Arabien faktisk særdeles god kontrol med Qatar, der på det tidspunkt set fra Riyadh var en konservativ wahhabistisk mønsterstat, som i den gamle emirs øjne nød godt af Saudi-Arabiens omsorg.

Men hans søn ville det anderledes og gennemførte en paladsrevolution og tog magten: Qatar skulle moderniseres, og det skulle ske ved på den ene side at udvikle en teknik, der kunne gøre det muligt at udskibe flydende gas fra verdens tredje største gasfelt, og det lykkedes, hvilket betød, at milliarderne begyndte at strømme ind; på den anden side skulle samfundet moderniseres gennem omfattende reformer af især uddannelsessystemet, hvilket også er sket trods modstand fra den stærkt konservative qatarske befolkning, der ikke havde megen lyst til at sende deres børn, navnlig piger, i moderne skoler, som underviste $i$ andet end koranen, herunder engelsk sprog og naturvidenskab.

Til at forestå denne reformering af samfundet og uddannelsessystemet etablerede emiren og hans hustru Qatar Foundation, som såvel nationalt som internationalt har sat sit præg på udviklingen af Qatar som en moderne, rig og trods sin ringe størrelse bemærkelsesværdig indflydelsesrig stat.

Den unge og veluddannede emir var fra starten bevidst om, at denne udvikling ville møde modstand hos nabolandene og ikke mindst Saudi-Arabien, der reagerede prompte med allerede i 1995 at orkestrere et modkup og med støtte fra UAE gentage et kupforsøg året efter. Begge kup mislykkedes, og emiren reagerede bl.a. ved at fratage op mod 5.000 qatarer med saudiarabiske sympatier deres statsborgerskab og sende dem ud af landet. Religiøst orienterede Qatar sig under hans ledelse i stigende grad mod Det Muslimske Broderskab og væk fra den saudiske wahhabisme, der ellers havde et godt tag i den qatarske befolkning efter mange års saudiarabisk dominans.

Dette var selvsagt ikke nok til at slippe ud af Saudi-Arabiens greb, og allerede i 1996 blev al-Jazeera etableret i Doha med støtte fra emiren. Den nye satellitkanal skulle være en arabisk pendant til BBC World og udviklede sig hurtigt til et særdeles veldrevet og professionelt journalistisk medie, der opnåede stor popularitet $\mathrm{i}$ det arabiske mellemøsten. Som den amerikanske mellemøstforsker David Lynch har dokumenteret i sin bog om al-Jazeera, blev kanalen en hovedfaktor i opbygningen af det, man kan kalde en arabisk offentlighed, ved at være et mediealternativ til de stærkt censurerede statsmedier, som ingen gad se på. 
Med al-Jazeera fik araberne i hele Mellemøsten mulighed for at se professionelt producerede dokumentarer og reportager, debatprogrammer og naturligvis underholdning. Den arabiske offentlighed blev yderligere udviklet, da de sociale medier holdt deres indtog i regionen, og folk strømmede til de lokale supermarkeder, der var fremsynede nok til at etablere internetcafeer.

Al-Jazeera og de sociale medier revolutionerede den arabiske offentlighed og de arabiske medier og formidlede til stor ærgrelse for diktatorerne og de konservative enevældige konge- og emirfamilier kritiske reportager af den mellemøstlige elendighed. Og centrum i denne medierevolution var Doha i Qatar.

Men en medierevolution var heller ikke nok til at holde Saudi-Arabien fra døren, så emiren involverede Qatar i allehånde internationale forhold som mægler i konflikter, støtte til oppositionsgrupper og altid til dem, Saudi-Arabien ikke kunne lide, hvilket skete i både Syrien, Yemen, Libyen og Egypten. Det hele naturligvis hjulpet godt på vej af de mange gasdollar, som i rigelige mængder tilflød de steder, hvor Qatar ville have indflydelse eller gøre sig vigtig.

Gang på gang forsøgte Saudi-Arabien at tvinge Qatar til en mere loyal politik. Det skete dels direkte gennem åbne konflikter, herunder om grænsen mellem de to stater, eller gennem GCC.

\section{Sikkerhedspolitik i Golfen}

I 1820 havde briterne indgået aftaler med emirfamilierne på Golfkysten og garanteret deres sikkerhed mod at have adgang til havne og baser i de små stater, som briterne kunne bruge som mellemstationer på vejen til og fra Indien - Golfen lå omtrent midtvejs mellem det britiske hovedkvar- ter i Cairo og Indien, hvoraf betegnelsen 'Mellemøsten' opstod.

Det hensygnende britiske imperium trak sig ud af Golfen i 1971 og efterlod de arabiske Golfstater ubeskyttede. I stedet rykkede USA ind og opbyggede en ny sikkerhedsarkitektur, der skulle sikre olieinteresserne og sørge for at holde Sovjetunionen borte fra Den Persiske Golf, hvilket var blevet kompliceret både af den iranske revolution i 1979 og af Sovjetunionens invasion af Afghanistan i juledagene samme år. Det sidste tolkede USA som en sovjetisk vej til Golfen, der kun ligger godt 400 $\mathrm{km}$ fra Afghanistan. Amerikanerne indledte derfor et tæt sikkerhedspolitisk samarbejde med de arabiske Golfstater, som i 1981 blev enige om at oprette GCC, der på sigt både skulle være et forsvarssamarbejde og en økonomisk union.

GCC har lige siden været præget af interne konflikter og uenigheder. Selvom der er oprettet en fælles forsvarsenhed, Peninsula Shield (der blev brugt som dække for Saudi-Arabien og UAE's invasion i Bahrain i 2011), er den mest en papirtiger. De enkelte stater har sikkerhedspolitisk været alt for nervøse til at overdrage forsvaret af deres suverænitet til et fælles hær, som de frygtede kunne bruges til at tvinge dem ind under saudisk hegemoni.

Uenighederne har tillige drejet sig om forholdet til Iran, hvor Qatar prioriterer gode forbindelser begrundet i, at Iran og Qatar deler et stort gasfelt. Internt i UAE har der også været uenighed, fordi Dubai økonomisk og demografisk har tætte forbindelser til Iran, mens Abu Dhabis linje er tættere på den saudiske konfrontationspolitik mod Iran. Både Oman og Kuwait ønsker af økonomiske grunde forbindelser til Iran, mens Bahrain, der har et shiamuslimsk befolkningsflertal, men er re- 
geret af en sunnimuslimsk kongefamilie, alene ser Iran som en trussel.

Beslutningsprocesserne i GCC er helt uigennemskuelige, hvilket skyldes de autoritære politiske regimer, der enevældigt ledes af inderkredsene omkring de seks landes regenter. Selvom GCC har store årlige møder med generalforsamling og hele molevitten, er det i realiteten repræsentanter for de seks ledende regerende

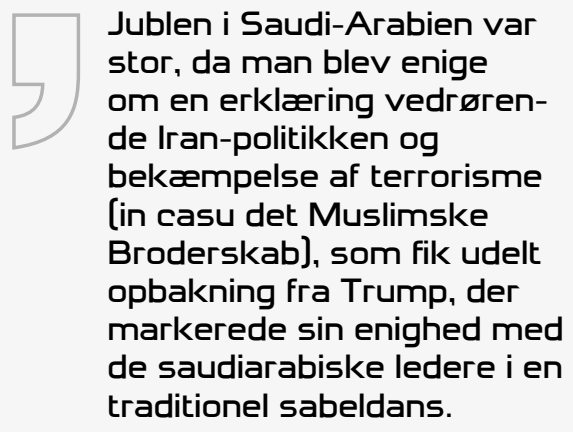

familier, der træffer de afgørende beslutninger, når de besøger hinanden i deres respektive hovedstæder.

Under den store Bahrain-krise i 2011 blev splittelsen internt i GCC udstillet i fuldt flor, da Saudi-Arabien erklærede, at dersom kongefamilien i Bahrain ville imødekomme oppositionens krav om overgang til konstitutionelt monarki og demokrati, ville Bahrain blive indlemmet som provins i det saudiarabiske kongerige.

Ikke desto mindre forsøger Saudi-Arabien og UAE gang på gang at bruge GCC som løftestang til at banke en fælles politik efter deres prioriteringer på plads. Således under GCC's topmøde i maj 2017 hvor USA's præsident Donald Trump deltog som officiel gæst. Jublen i Saudi-Arabien var stor, da man blev enige om en erklæring vedrørende Iran-politikken og bekæmpelse af terrorisme (in casu det Muslimske Broderskab), som fik udelt op- bakning fra Trump, der markerede sin enighed med de saudiarabiske ledere i en traditionel sabeldans.

\section{Fejlslagne mæglinger}

Qatar havde imidlertid ingenlunde tænkt sig at rette ind og fortsatte ufortrødent sine forbindelser til Iran, undlod at udlevere personer, som UAE anså for at være terrorister og ønskede udleveret til straf, og al-Jazeera fortsatte sin kritiske dækning af forholdene på Den Arabiske Halvø.

Dertil kom en spektakulær historie om, at højtstående medlemmer i Qatars kongefamilie var blevet taget som gidsler af en shiamuslimsk milits i Irak under en jagttur, og at Qatar både havde forhandlet med militsen uden om regeringen i Irak og betalt et monstrøst pengebeløb til Iran for at få gidslerne hjem.

Dette blev et af flere påskud for at indlede blokaden mod Qatar, som Saudi-Arabien selvsikkert mente havde opbakning fra USA efter det succesfulde GCC topmøde med Trumps sabeldans. Og Trump bekræftede straks ved begejstret at erklære, at blokaden mod Qatar nærmest var hans ide, men kom på lidt andre tanker, da hans udenrigsminister og forsvarsminister mindede ham om, at Qatar med al-Udeid basen og CENTCOM strategisk er særdeles vigtige i USA's krig mod Islamisk stat.

Herefter overlod Trump det til udenrigsminister Rex Tillerson at mægle i konflikten, hvilket der indtil videre stort set intet er kommet ud af bortset fra en samarbejdsaftale mellem USA og Qatar om terrorismebekæmpelse, som kun fik hånende ord med på vejen i Saudi-Arabien.

Umiddelbart efter krisens udbrud tilbød Kuwaits emir at fungere som mægler. Både Kuwait og Oman har store interesser 
i, at konflikten bliver løst mindeligt, eftersom begge stater i lighed med Qatar plejer interesser med Iran og frygter at blive klemt, hvis krisen eskalerer.

Ved blokadens start var Qatar blevet præsenteret for $13 \mathrm{krav}$, som de fem arabiske lande stillede for at genoptage relationerne til Qatar og ophæve sanktionerne. Ud over Iran, som Qatar skulle stoppe sine forbindelser til, handlede det om terrorismebekæmpelse - læs Det Muslimske Broderskab og Hamas, som Qatar skulle ophøre at have forbindelser til. Dette indebar naturligvis økonomisk støtte tillige med udvisning af en række personer, som Qatar havde givet ophold til, og som de fem lande anså som terrorister. Dertil skulle al-Jazeera og andre Qatar-støttede medieplatforme lukkes, og endelig skulle den militærbase, som Tyrkiet havde taget i anvendelse i Qatar året inden, nedlægges og de tyrkiste soldater sendes hjem til præsident Erdogan.

Qatar afviste alle beskyldninger og nægtede at indfri kravene. Efter nogle uger med såvel den kuwaitiske emirs som Tillersons mægling blev de 13 krav skrevet om til seks principper. Nærlæser man dem, er det dog stort set de samme krav nu blot formuleret i mere indpakkede diplomatiske vendinger.

De er derfor fremdeles helt uacceptable for Qatar, ligesom de også ville være et brud på international lov om indblanding $\mathrm{i}$ andre suveræne staters indre anliggender og allianceforhold. Det sidste har Tyrkiets præsident Erdogan ikke tøvet med at gøre opmærksom på og med sædvanlig patos reageret ved at sende endnu flere tyrkiske soldater til basen i Qatar.

Tyrkiet har nære relationer til Qatar: begge stater har gode relationer til Det Muslimske Broderskab, og Tyrkiet kan i høj grad bruge Qatar i sin nationalistiske
Syrien-politik, der siden Tyrkiets tilnærmelse til Rusland og Iran helt og holdent drejer sig om kampen mod kurderne, som Erdogan under ingen omstændigheder vil have får nogen selvstændighed i Syrien. Den tyrkiske militære tilstedeværelse komplicerer det selvsagt for Saudi-Arabien og UAE, der ikke uden at skabe en stor internatonal krise kan sende deres militær ind i Qatar, således som de gjorde i Bahrain i 2011.

\section{Krisen kan blive langvarig}

Dermed er krisen fastlåst: Qatar vil ikke indfri kravene og klarer sig under blokaden med støtte fra Tyrkiet og Iran uden at være alt for anfægtet af den. Naturligvis giver blokaden Qatar en række problemer både økonomisk, i international politik og i Qatars politik i Mellemøsten. Men formentlig ikke mere end at qatarerne vil fastholde deres afvisning af kravene.

Omvendt er der hidtil intet, der tyder på, at de fem arabiske blokadestater med Saudi-Arabien og UAE i spidsen vil opgive at banke Qatar på plads. De henviser til konflikten i 2014, hvor de begge sammen med Bahrain havde trukket deres diplomater hjem fra Qatar i godt otte måneder, og hvor de diplomatiske forbindelser først blev genoptaget, efter at Qatar havde underskrevet en aftale om at begrænse al-Jazeeras aktiviteter i Saudi-Arabien og andre steder samt slå ned på Det Muslimske Broderskab.

UAE og Saudi-Arabien begrunder bl.a. den nye blokade med, at Qatar aldrig har levet op til aftalerne fra 2014, og derfor stiller de i 2017 hårdere krav, der ud over de nævnte også indebærer decideret rapporteringspligt til Saudi-Arabien som vil kontrollere at Qatar efterlever kravene.

Det er således meget vanskeligt at se en løsning på konflikten. Saudi-Arabien og 
de fire andre lande kan forsøge at eskalere konflikten ved $\mathrm{fx}$ at inddrage Kuwait og især Oman, som efter blokaden stiller havnefaciliteter til rådighed for Qatar. Det vil imidlertid være højt spil og risikere at føre til en opløsning af GCC, hvilket vil forværre den sikkerhedspolitiske situation i Golfen betydeligt. For selvom GCC langt hen ad vejen er en papirtiger, er den dog et forum for gensidige kontakter og aftaler mellem de seks Golfstater, og forsvinder dette forum, vil dørene være åbne til, at andre internationale spillere som Tyrkiet, Iran, Rusland og Kina kan få fri adgang til at lave bilaterale sikkerhedspolitiske aftaler med de golfarabiske stater. Med andre ord vil konflikterne i det olie- og gasrige Golfområde blive yderligere kompliceret og meget mere uforudsigelige med de risici, det medfører.

Da den saudiske ambassade i Teheran blev angrebet, efter at saudierne i januar 2016 have halshugget mere end 50 shiamuslimer, nedjusterede Qatar sine diplomatiske forbindelser med Iran. Efter embargoen har Qatar reageret ved bl.a. at genoptage og opgradere diplomatiske forbindelser til Iran. Som det ser ud nu er det atter Iran, der vinder ved Saudi-Arabiens politik, idet Iran helt imod Saudi-Arabiens og UAE’s ønsker faktisk øger sin indflydelse i det arabiske Mellemøsten.

Det mest sandsynlige udkomme af embargoen mod Qatar synes at være en skilsmisse mellem Qatar og GCC, og dermed er situationen i Golfen blevet yderligere kompliceret, og Saudi-Arabien har endnu engang skudt sig selv i foden og gjort sin rolle i den regionale politik mere besværlig. 